\title{
An introduction to the special issue of the BSGF
}

\section{Insights into the geology and paleontology of Siberia from French-Siberian collaboration in Earth Sciences}

\author{
Guest Editors: TANIEL DANELIAN ${ }^{1}$, MARC JOLIVET $^{2}$ and DMITRI IONOV ${ }^{3}$
}

The idea for this thematic issue was introduced at the end of the Earth Sciences conference of the French-Siberian Centre for Research and Training (FSCRT) that took place on August 21 ${ }^{\text {st }}, 2014$ in Barnaul (Siberia; fig. 1). The meeting was followed by a geological fieldtrip, led by Dr. Michaïl Buslov (Novosibirsk), which allowed most of the participants to appreciate the geology of the mountainous region of Gorny-Altai.

The French-Siberian Centre was set up following the signature in September 2012 of an agreement between the Centre National de la Recherche Scientifique (CNRS) and a consortium of 19 French Universities, on one side and the Siberian Branch of the Russian Academy of Sciences
(SB-RAS) and a consortium of 13 Siberian Universities, on the other side.

It involved a call for joint French-Russian collaborative proposals with the objective to enhance or initiate scientific collaboration between French and Siberian Universities and/or Research Institutes. We were successful with a multidisciplinary proposal in Earth Sciences (PI T. Danelian and N.V. Sennikov) entitled "Geodynamic and paleoecosystem evolution in Siberia", funded by the French Ministry of Education, Higher Education and Research and the Siberian Branch of the Russian Academy of Sciences (2013-2014). The two main objectives of our project were:

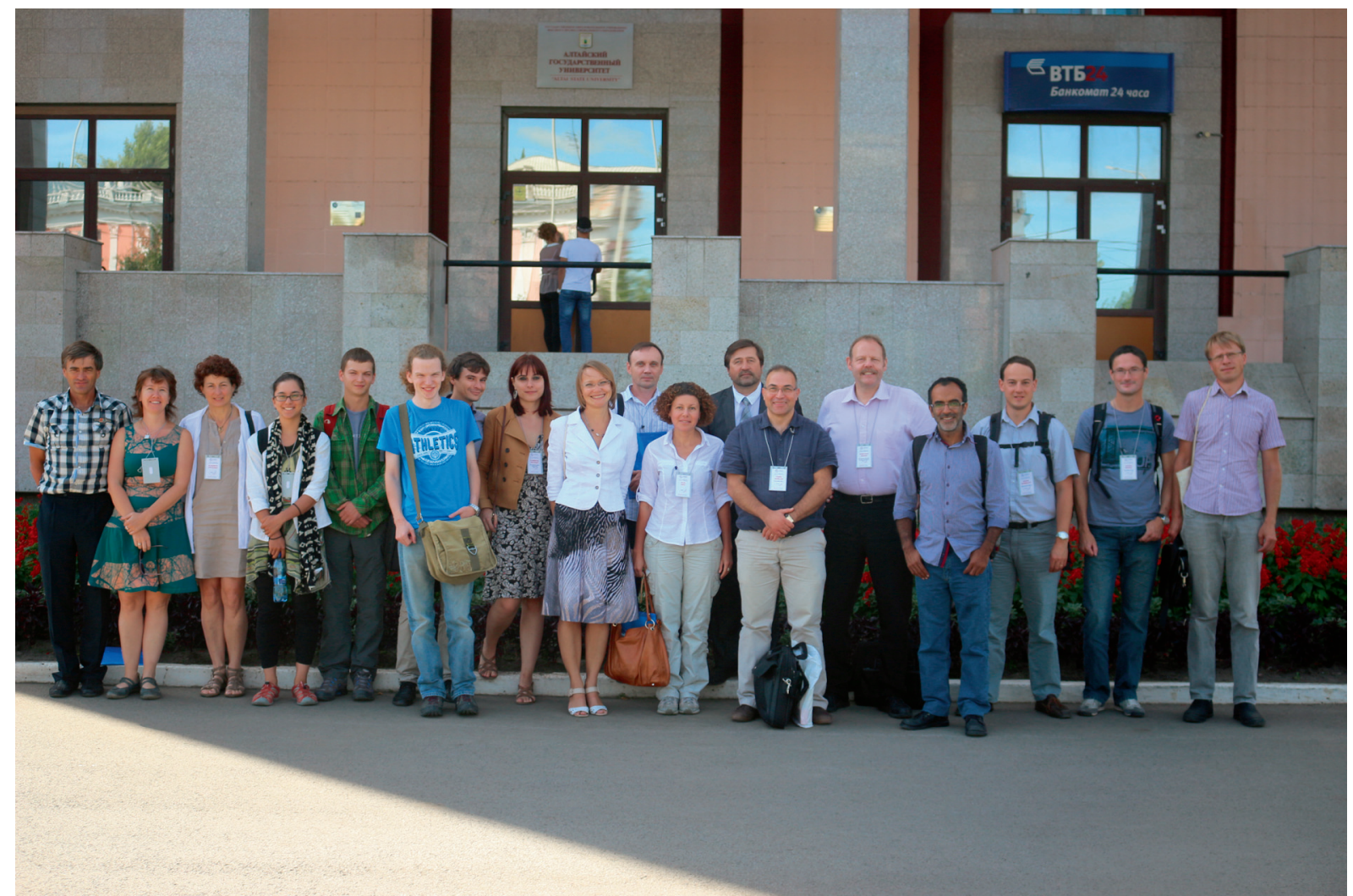

FIG. 1. - Participants to the Barnaul meeting, from left to right: Michaïl Buslov (Novosibirsk), Emilie Thomassot (Nancy), Elisabeth d'Eyrames (Nancy), Yumi Kitayama (Nancy), Anton Kolesnikov (Novosibirsk \& Lille), Gauthier Hainault (Lille), Igor Kosenko (Novosibirsk), Clémentine Colpaert (Lille \& Novosibirsk), Yana Bazhenova (Tomsk), Igor Korovnikov (Novosibirsk), Olga Obut (Novosibirsk), Alexey Tishkin (Barnaul), Taniel Danelian (Lille), Jean-Paul Deroin (Reims), Cesar Witt (Lille), Maxime Gaumeaux (Reims), Claude Monnet (Lille), Dmitriy Grazhdankin (Novosibirsk).

1. Univ. Lille, CNRS, UMR 8198 - Evo-Eco-Paleo, F-59000 Lille, France

2. Laboratoire Géosciences Rennes, Université Rennes 1 - CNRS/INSU, OSU Rennes, Rennes, France

3. Géosciences Montpellier, Université de Montpellier \& UMR-CNRS 5243, 34095 Montpellier, France

Manuscript accepted on February 14, 2017 
1) to strengthen or initiate research collaboration between 5 CNRS laboratories hosted in 5 different French Universities (Lille 1, Rennes 1, St Etienne, Chambéry, Paris 6) and 3 Research Institutes of the Siberian Branch of the Russian Academy of Sciences (Trofimuk and Sobolev at Novosibirsk, Earth Crust at Irkutsk), together with 3 Siberian Universities (Novosibirsk, Tomsk, Krasnoyarsk);

2) to promote student exchanges in Earth Sciences by making a good link between research and student training. Thus, in most cases, student mobility has been integrated in bilateral research projects.

Our project was built essentially on a number of existing collaborations and was structured around four inter-related Work Packages (WP), which are as follows:

- WP 1: Palaeo-biodiversity and Palaeo-environments: insights from the Siberian record

- WP 2: Formation and Precambrian evolution of the Siberian craton

- WP 3: Tectonics - Erosion and Sedimentation in the Transbaikal region: from Mesozoic extension to Cenozoic rifting

- WP 4: Coordination, communication and academic exchanges, involving also training of Master 2 and $\mathrm{PhD}$ students.

The present special issue is divided into three chapters, each one presenting the background and evolution of each of the three thematic WP, as well as the corresponding scientific contributions. See figure 2 for the study areas detailed in this volume.

\section{PALAEOBIOLOGY, BIOSTRATIGRAPHY AND PALAEOENVIRONMENTS}

Initial contacts between Lille and Novosibirsk were established in the years 2000 around the IGCP project 503 "the
Great Ordovician biodiversification Event" (O. Obut, N. Sennikov, T. Servais, T. Vandenbroucke), but also through activities organized around the Devonian stratigraphic subcommission (A. Blieck, C. Crônier, O. Obut).

Discussions between T. Danelian and O. Obut during the 2009 InterRad Conference in Nanjing (China) were decisive in placing the foundations for the development of a strategic partnership between Lille and Novosibirsk, since the two parties were successful in obtaining a 2-year funding (2010-2011) to collaborate on "the biodiversity of pelagic ecosystems in the Early Palaeozoic", following a CNRS - Russian Academy of Sciences (RAS) call. This collaboration was mutually beneficial and boosted research activities on interesting paleontological questions.

The pelagic sequences of the Shashkunar Formation that crop out in the Ak-Kaya section of the Altaï mountains contain the oldest currently known radiolarian record, first reported by Obut and Iwata [2000]. Since molecular phylogenetic trees establish that Polycystine radiolarians (those with a siliceous skeleton) are closely related to Foraminifera, it is interesting to compare in detail the oldest record of these two Rhizarian lineages, both known since the Cambrian. Thus, interest was renewed for the Ak-Kaya section, as it became a target for the above mentioned CNRS-RAS project; recent joint French-Russian fieldwork led to the discovery of additional radiolarian material of clear affinity to Archeoentactiniids, known from the Middle Cambrian of Australia [Won and Below, 1999; Pouille et al., 2011]. Constraining the age of the radiolarian bearing strata is crucial and the lower Botoman trilobites discovered recently by Korovnikov et al. [2013] are important in this respect. The paper by Sennikov et al. [2017] reports on ongoing research of the fossil and sedimentary record from the Ak-Kaya; additional trilobites, known previously only from the upper Atdabanian, are found only slightly above the lower Botoman levels. Based on their paleoecological

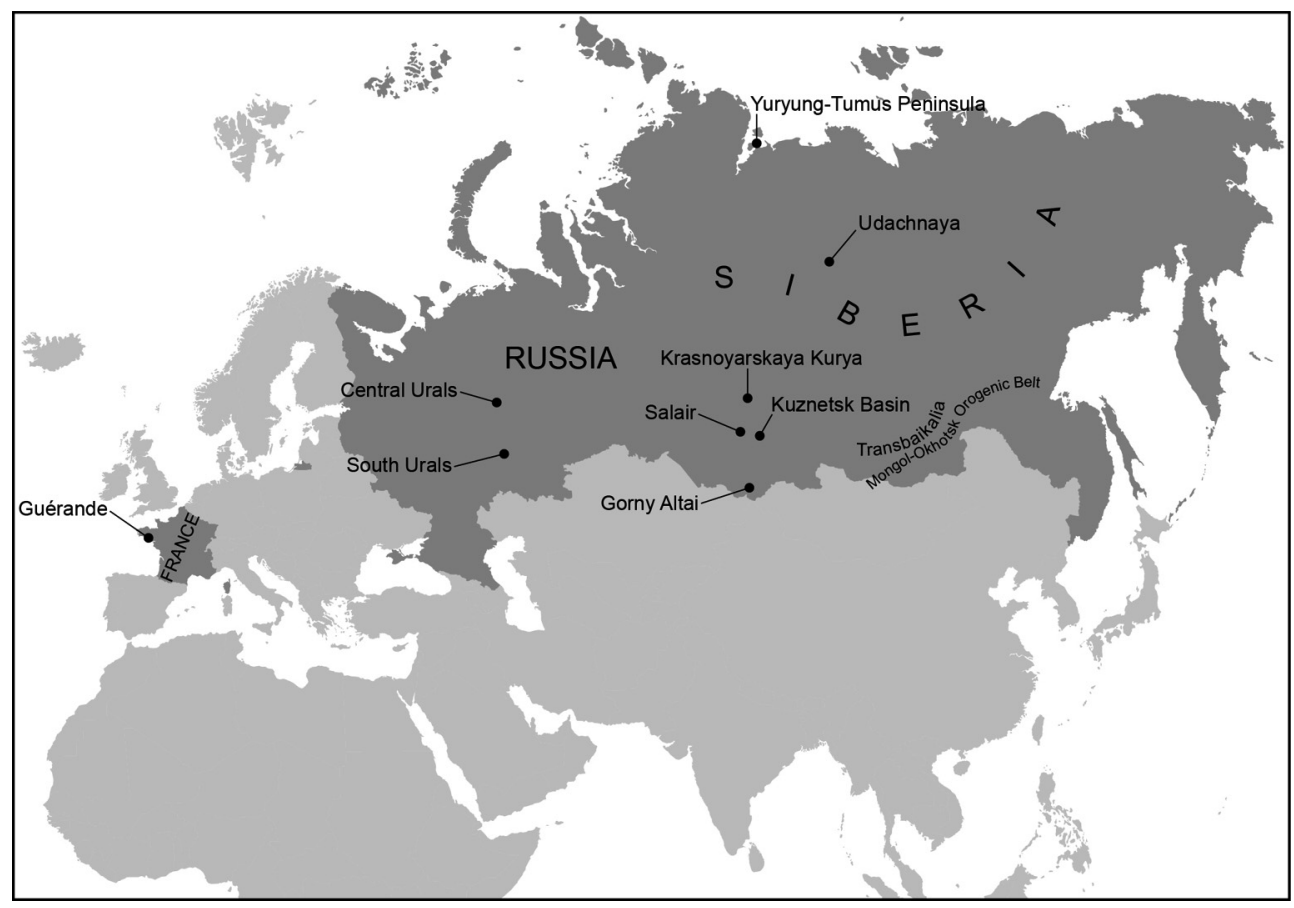

FIG. 2. - Study areas, detailed in the eleven papers of this volume. 
affinity they may be interpreted as reworked in lower Botoman strata or alternatively their age range may be extended up to the lower Botoman. It is important to highlight that all these trilobites are found ca. $30 \mathrm{~m}$ below the radiolarian bearing siliceous interval of the Ak-Kaya section (fig. 3). Thus, the recovery of the Small Shelly Fossil (SSF) Rhombocorniculum cancellatum from the radiolarian-bearing interval (reported also by Zybin et al. [2000]) is very important, as it is only known from the upper Atdabanian-lower Botoman [Kouchinsky et al., 2015]; in combination with the Lower Botoman trilobites found $30 \mathrm{~m}$ below, it leaves little doubt that the radiolarians found in this section are of early Botoman age. The paper by Sennikov et al. describes also well preserved archaeocyaths and small shelly fossils (SSF) found in three distinct sections of the Gavrilovka Formation, a thick biogenic limestone sequence known from the Salair; these limestones were accumulated along reef buildups surrounded by lagoons with archaeocyaths that were formed on top of upper Proterozoic-lowermost Cambrian volcanic rocks. Sennikov et al. confirm the Atdabanian age of the Gavrilovka Fm but they also establish, for the first time, the presence of the Gordonicyathus howelli archaeocyath zone. These results will allow improved comparisons to be made between the carbonate sequence of Salair and the Siberian platform.

In September 2011 T. Danelian had the opportunity to establish contacts with the Novosibirsk State University (NSU) and to explore the possibility of student exchanges at Master-2 level. Following extensive discussions with the NSU International Office and the Faculty of Earth Sciences, a research-driven Master double degree agreement was signed in June 2012 between the University of Lille - Sciences \& Technologies (Lille 1) and the NSU. It has been largely based on joint French-Siberian research projects.

Clémentine Colpaert was the first French student to benefit this program. Her Master thesis, prepared in Novosibirk during the first half of 2014, concerned the study of Lower Carboniferous foraminifera from the Kuznetsk basin. The studied sections from Siberia are important, as in the years after the Second World War they had significantly contributed to our understanding of the Lower Carboniferous foraminiferal record from the former USSR. It was interesting to have a fresh look at these old collections, stored initially at Novosibirsk, not only because the Lower Carboniferous limestones of the Kuznetsk basin accumulated in the high latitudes (and low temperatures) but also for comparison with the improved biostratigraphic framework of the Ardennes region (France and Belgium) and its correlation to the geological time scale. However, as the initial foraminiferal collections were regrettably lost, new joint French-Russian fieldwork was organised in July 2013 in which Clémentine took part. The results of this study are presented in the paper by Colpaert et al. [2017], including a biofacies analysis of the studied sections. Bioclastic limestones that accumulated in a low energy inner ramp environment contain a characteristic assemblage of plurilocular foraminifera that can be correlated with the foraminiferal biozone MFZ4 of the Ardennes region. The latest early Tournaisian age is also supported by conodonts found during this study. The foraminiferal assemblage is valuable to clarify the systematic classification of poorly known Tournaisian foraminiferal lineages with as a result the introduction of a new superfamily, the Septabrunsiinoidea, for which SW Siberia is considered as its centre of radiation during the early Tournaisian towards $\mathrm{N}$. America, S. China and western Tethys.

Benoît de Lagausie is another student from Lille who worked on his Master thesis in Novosibirsk, where he spent 5 months in early 2016 to study Middle Jurassic belemnites from the arctic Siberia, collected by Oksana Dzyuba (his supervisor) in 2009. This region is important for understanding paleoclimatic changes during the Jurassic; it has also a potential for the exploration of hydrocarbon resources. Because of its relatively restricted paleogeographic setting and its high latitudinal position in the Jurassic, as today, it has allowed the development of endemic fauna. Endemicity is a problem for interregional correlations, especially because the standard Ammonite zones are

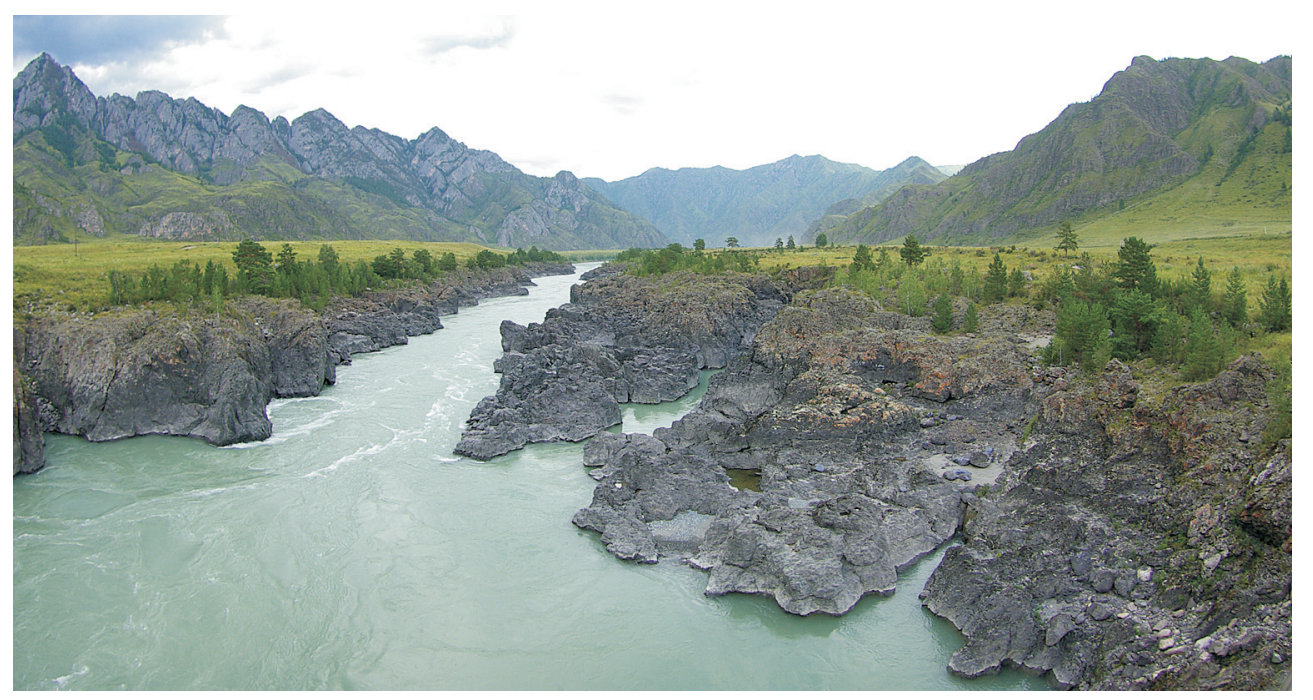

FIG. 3. - Lower Cambrian oceanic basalts and overlying sedimentary sequence of the Gorny Altai. In the middle: massive basalts cropping out along the Katun River. At the background, on the left: view over the Lower Cambrian sedimentary sequence overlying the basalts (Ak-Kaya section). Courtesy of Nikolay Sennikov. 
mainly defined in the tropical/Tethyan realm. The study by De Lagausie and Dzyuba [2017] allowed to establish the presence in the arctic Siberia of new biostratigraphically important belemnite species and to define in detail the stratigraphic range of several others; the study thus introduces two new belemnite biozones, useful for large scale correlations based on belemnites, especially between the Boreal (arctic Siberia, north European Russia) and the Subboreal (central Russia) realms. The paper further refines the belemnite biozonation across the Bajocian-Bathonian boundary in the arctic Siberia. Their study allows to record, for the first time in Siberia, the occurrence of the belemnite species Paramegateuthis subishmensis, known previously only from the Tethyan realm (Bulgaria), clarifying consequently the correlation of 2 Boreal ammonite zones with the standard ammonite biozonal scheme.

The paper by Seuru et al. [2017] presents the results obtained during Samuel Seuru's Master thesis in early 2015 at Tomsk; this French student benefitted a research-driven Master double degree agreement signed in June 2014 between Lille 1 and Tomsk State University (TSU). Krasnoyarskaya Kurya is one of the four most important woolly Mammoth "cemeteries" in western Siberia. The paper presents essentially field observations and fossil material collected during an excavation conducted in August 2014, in which Samuel took part. The study is novel for this Siberian site, as in addition to the anatomical and paleobiological analysis of the fossil remains there is also a taphonomic and archeozoological approach. It attempts to address the question whether the origin of bone accumulation in the two fossiliferous levels is natural or whether alternatively it was driven by partial or total human activity, since rare Palaeolithic artefacts were found at the site during previous excavations. The meticulous study of Seuru et al. suggests that the three mammoths of the younger level (including a juvenile) lived at ca. $24 \mathrm{Ka} \mathrm{BP}$, just before the Late Glacial Maximum, in an open grassland (steppe) environment (supported also by isotopic data on collagen) and that they accumulated following natural death in an ancient floodplain. The four mammoth individuals ( 2 juveniles and 2 adults) reconstructed from the lower fossiliferous level are interpreted as accumulations of animals trapped in an oxbow lake, from which humans and carnivores took away some useful parts.

Our project did not only enhance established research collaborations between Lille and Novosibirsk, it also increased the number of researchers involved at both sides, with a greater diversity of scientific questions and topics.

One of these examples is the collaboration initiated by T. Danelian (Lille) and D. Grazhdankin (Novosibirsk), which also involved researchers from the University of Reims Champagne-Ardenne (M. Gommeaux). The main objective was to improve the understanding of some Ediacaran fossils in the light of observations made on modern morphostructures formed on the surface of microbial mats developed in ponds of the Guerand Salinas (Brittany, France). Some of these structures (e.g. concentric rings) were noticed previously by German microbiologists working in the salinas and were tentatively compared with Cyclomedusa, an Ediacaran discoidal fossil [Grazhdankin and Gerdes, 2007].
Our collaboration was supported by the CNRS, following a bilateral call with the Russian Academy of Sciences ("Geobiology of Ediacaran and modern microbial communities"; 2014-2015; PI T. Danelian and D. Grazhdankin). In 2014 , it was also supported by the University of Lille - Sciences \& Technologies, through funding of a Bonus Qualité Recherche (BQR) International, as well as a seed grant of the Research Federation on Environmental studies IREPSE (PI C. Poux and T. Danelian). Finally, in 2016 the CNRS-INSU (Institut National des Sciences de 1'Univers) funded the INTERRVIE project "Ediacaran-type morphostructures formed in microbial mats of hypersaline ponds (Guerande, Brittany); insights to Ediacaran Geobiology".

The first joint fieldwork in the Guerand Salinas (June 2014) gave the opportunity to T. Danelian and D. Grazhdankin to discuss the involvement of a $\mathrm{PhD}$ student from Novosibirsk (A. Kolesnikov) on a topic that requires insights from modern microbial mats for the interpretation of some late Ediacaran fossils, especially those that are dominant at the aftermath of the Kotlinian crisis that led to the disappearance of soft-bodied organisms [Grazhdankin, 2014]. A Metchnikov PhD grant of the French Embassy in Moscow allowed Anton to be enrolled, since Octobre 2014, in a co-tutorial $\mathrm{PhD}$ between the Trofimuk Institute of the SB-RAS and the University of Lille.

During fieldwork conducted in July 2015 in the Guerand salinas, Kolesnikov et al. [2017] came across a morphostructure that recalls Arumberia, an enigmatic Ediacaran fossil characterised by a number of fine but macroscopic subparallel ridges, preserved on the bedding plane of sandstones [Kolesnikov et al., 2012]. Arumberia is amongst the most difficult Ediacaran fossils to interpret; its nature (organic $v s$ inorganic) and origin is a subject of debate. Interestingly, it appears to be abundant in the late Ediacaran time in terrigenous sedimentary rocks accumulated in very shallow water depositional environments that were affected by dessication and fluctuations in salinity. The paper describes in detail the arumberiamorph structure observed in the Guerand Salinas, as well as its environmental setting. The authors discuss the nature of the subparallel macroscopic wrinkled structures (called "rugae") formed on the surface of the microbial mat and conclude that they are of biological origin, possibly formed to increase resistance to environmental stress, although they refrain themselves from interpreting them as a response to any single environmental parameter. They finally discuss the widespread presence of Arumberia in the terminal Ediacaran with respect to the environmental perturbations of the Kotlinian crisis [Kolesnikov et al., 2015].

\section{FORMATION AND PRECAMBRIAN EVOLUTION OF THE SIBERIAN CRATON}

The French-Siberian collaboration in studies of mantle and lower crustal materials from the Siberian craton began in 2006 when D.A. Ionov took a professor's position at the Jean Monnet University (UJM) in Saint Etienne, France. Initially, it involved a pilot study of a collection of fragments (xenoliths) of mantle rocks in the Udachnaya kimberlite, the site of a major diamond mine in the central Siberian craton, provided by I. Ashchepkov from Novosibirsk [Ionov 
et al., 2010]. A broader research effort, coordinated by D.A. Ionov, began a few years later when several UJM researchers (J.-Y. Cottin, J.-F. Moyen, B. Moine) visited Novosibirsk to outline and launch a collaboration program involving A. Golovin, A. Korsakov, N. Pokhilenko and their colleagues. As a result, a broad range of studies of larger and more diverse collections of geologic materials from $\mathrm{Si}$ beria began both in St-Etienne and at the University of Montpellier (UM), which soon joined the project [Agashev et al., 2013; Bascou et al., 2011; Goncharov et al., 2012]. Importantly, L.-S. Doucet, a PhD student at St-Etienne supervised by D.A. Ionov, worked on his $\mathrm{PhD}$ thesis in 2009-2012 that was fully based on the collaboration project with researchers from Novosibirsk [Doucet et al., 2012, $2013,2014]$. The joint work rapidly produced important results, primarily on mantle peridotite xenoliths, published in 2010-2016 in over a dozen papers, which made important, in some cases ground-breaking, contributions to constraining the age, origin and evolution of the lithospheric mantle and lower crust of the Siberian craton [e.g., Ionov et al., 2015a, b; Moyen et al., 2017].

This work was financed by a PICS (international collaboration funding scheme of the French National Centre for Scientific Research, CNRS) project No5812 Geochemical and isotopic tracers of primitive Earth in the Siberian craton in 2011-2013 as well as several grants to D.A. Ionov by the National Institute of Sciences of the Universe (INSU) of the CNRS in 2010-2016.

Furthermore, the joint projects with Novosibirsk have contributed to the development of international collaboration of the UJM and UM with leading research centers in the US, Belgium, China, Germany, Italy, where samples from Siberia were studied [Doucet et al., 2014, 2015, 2016; Ferré et al., 2013; Jean et al., 2016; Nimis et al., 2015; Xia et al., 2017], and further work is under way.

The two papers on the Siberian craton included in this volume stem from the development and extension of the research themes to new directions, with new types of materials, new research tools and approach. One of them [d'Eyrames et al., 2017] is a detailed geochemical and mineralogical study of kimberlites, the host rocks of various xenoliths carried by their parental magmas from the mantle and deep crust when they erupted some 100-400 Ma ago. The other one [Radu et al., 2017] is focused on a particular type of eclogite xenoliths, mantle rocks that most likely derive from ancient oceanic crust subducted to the mantle.

Kimberlites are very unusual igneous rocks because they are very rich in volatile components and in alkalis. They only occur in the oldest and thickest continental domains (cratons) and are the main sources of diamonds. Their origin and sources remain enigmatic in spite of several decades of intensive work. Two major problems in their studies are that kimberlites: (1) are sensitive to alteration by meteoric water and hydrothermal fluids, hence are usually strongly serpentinized and (2) contain lots of xenogenic materials, from olivine crystals to xenoliths of mantle to upper crustal rocks. Thus, it is not clear what mineralogical and chemical features of kimberlites are related to their sources in the deep mantle and what are the result of contamination and fractionation during and after their explosive emplacement. It is not surprising that a particular portion of the Udachnaya-East pipe composed of fresh, unserpentinized and water-poor kimberlite, has recently attracted much interest, as well as much controversy. Importantly, the dry kimberlite is anomalously rich in salts (both $\mathrm{Na}_{2} \mathrm{O}$ and $\mathrm{Cl}$ up to $6 \mathrm{wt} \%$ ) whereas the more common serpentinized rocks are salt-free. While some researchers view the "dry and salty" kimberlites as representing uncontaminated and unaltered crystallization products of pristine mantle magmas, others, by contrast, argue that their unusual features are due to assimilation of salt-bearing crustal rocks.

D'Eyrames et al. [2017] studied both the rare "dry and salty" and more common kimberlites from Udachnaya, in particular their sulfur contents and $\mathrm{S}$ isotopic compositions. Somewhat surprisingly, they found that the 'salty' kimberlite is unprecedentedly rich in sulfur (0.13-0.50 wt.\%) compared to its non-salty and altered equivalents. In the 'salty' kimberlite, most of the sulfur (up to 94\%) is present as sulfates, mainly in the fine-grained groundmass, which also contains $\mathrm{Na}$ - and K-rich sulfides (djerfisherites). Importantly, d'Eyrames et al. [2017] established that only the sulfides from the 'salty' kimberlite have S-isotope composition typical of the upper mantle (e.g. very similar to that in oceanic basalts), i.e. represent pristine mantle-derived rocks. By contrast, sulfides from the serpentinized kimberlites have high contents of the heavier ${ }^{34} \mathrm{~S}$ isotope and thus experienced contamination by typically ${ }^{34} \mathrm{~S}$-enriched components of crustal and hydrothermal origin as well as other post-eruption processes. Overall, their study presents important new arguments in the controversy on the origin of kimberlites as well as implications for the oxygen fugacity in the deep mantle and for the global S budget of the mantle.

Eclogites, rocks that consist of clinopyroxene (cpx) and garnet, but unlike peridotites contain no olivine, are commonly found as xenoliths in kimberlites in most cratons. The origin of eclogites continues to be debated even though most researchers consider them to be oceanic crustal materials subducted to the mantle and recrystallized at high pressures. The paper by Radu et al. [2017] focuses on a rare type of eclogites that, in addition to the bi-mineral association of garnet and cpx, also contain kyanite, an Al-rich silicate mineral. It provides new data on major and trace element compositions of minerals in kyanite eclogites from the Udachnaya kimberlite pipe in the central Siberian craton. It is commonly believed that the kyanite eclogites experienced 'metasomatism', i.e. that some chemical components were added to these rocks in the mantle, which resulted in the formation of a new mineral, kyanite. Radu et al. [2017], however, found anomalously high concentrations of elements $\mathrm{Sr}$ and $\mathrm{Eu}$ in the cpx in eclogites from Udachnaya and challenged the metasomatic origin of their samples. They argue that the $\mathrm{Sr}$ and Eu anomalies are a primary feature of their eclogites. Because such anomalies can only form in low-pressure environments where Al-rich mineral plagioclase is stable, i.e. in the Earth's crust, they cannot be a result of mantle metasomatism. They further examined published data on kyanite eclogites from other kimberlites worldwide and found broad similarities with their samples, which they see as evidence that crustal magmatic rocks were subducted to the mantle in the Archean, i.e. earlier in the Earth's history than commonly believed, probably in relation to craton accretion. 


\section{TECTONICS IN THE TRANSBAIKAL REGION AND ALTAÏ-SAYAN AREA}

The team led by M. Jolivet (CNRS - University Rennes 1, and previously University Montpellier 2) has been collaborating with the team from the Institute of the Earth Crust of the SB-RAS at Irkutsk (A. and S. Arzhannikov, S. Ivanov, V. Sankov, etc.) since 2003. This collaboration has led to a significant number of joint publications and $2 \mathrm{PhD}$ theses. Several joint projects have been funded, such as the INSU RELIEF project "Quantification des mouvements superficiels récents par géochronologie intégrée, traces de fission, $\mathrm{U}-\mathrm{Th} / \mathrm{He}$ et ${ }^{10} \mathrm{Be}$ : application à la region de Mongolie-Baikal" (2005-2007), two PICS (international collaboration funding scheme of the French CNRS) project "History of the Mesozoic relief in the Mongol-Okhotsk area (Siberia)": formation, size and destruction" (2008-2010) and "Tectonic and topographic evolution of the TransBaikal region during the Mesozoic to Recent" (2012-2014) also supported by the University Rennes 1 and the Russian Fund for Basic Research. Finally, through collaboration with C. Petit (Géoazur, Nice-Sophia-Antipolis) and M. Fournier (Université Paris 6) the French oil company Total also provided a 3 -year grant (associated to a $\mathrm{PhD}$ grant) for research conducted in the Patom range.

This collaborative work with Russian colleagues allowed studying a wide and complex area encompassing the Altay, Gobi Altai, western and East Sayan ranges and finally the Baikal and Transbaikal region, up to the Patom range (NE of lake Baikal). The research performed by the group has led to several major results including: a) the first description of the occurrence of a major Middle Jurassic to Early Cretaceous planation surface encompassing most of Central Asia and still preserved as relict plateaus in most of the active ranges; b) the general description and quantification of the topographic evolution of the Sayan, Primorsky, Patom and Transbaikal regions between the late Mesozoic and the onset of the Tertiary deformation; c) evidence for pre-India-Asia collision onset of deformation in the Baikal Rift System, implying that the rift was not initiated by the collision as previously supposed, and d) a new model for the joint tectonic evolution of the Baikal Rift System and the Transbaikal extension zone, involving continuity between the Mesozoic extension in those regions and the Tertiary rifting event. This last finding implies that the Baikal Rift is not a narrow rift as usually accepted but a wide rift zone affecting the Amuria plate several hundreds of kilometres towards the east.

Within the framework of the French-Siberian Centre for Research and Training, the agreement signed between the University of Rennes 1, the CNRS and the SB-RAS has allowed pursuing this fruitful collaboration, extending it to contacts in Novosibirsk (M. Buslov) and to collaborations with researchers from Ghent University in Belgium (J. De Grave, S. Glorie).

In this volume, each of various groups of authors focused mostly on a key geodynamic question that remains to be solved in southern Siberia: the closure, during the Mesozoic, of the Mongol-Okhotsk ocean that separated the Siberian craton from the Mongolia-North China continental block. The exact timing and modalities of this oceanic closure are still largely discussed as well as the potential existence of an associated orogeny and the type of topography that was created.

In their contribution, Demonterova et al. [2017] describe in detail the Jurassic sediments deposited in the Irkutsk basin, along the southeastern edge of the Siberian platform. They show that those detrital series have been deposited in a very short period of time, essentially the Aalenian, and mark an increase in the regional erosion rates. Using $\mathrm{Sm}-\mathrm{Nd}$ and detrital zircon $\mathrm{U}-\mathrm{Pb}$ geochronology data, they show that a major source of the detrital material corresponds to juvenile crust attributed to the Mongol-Okhotsk orogen that developed to the East in the Transbaikal area. This inference implies a rapid increase, during the Lower Jurassic-Middle Jurassic transition, of positive relief in the Transbaikal region, in response to the Mongol-Okhotsk orogeny.

The following contribution by Jolivet et al. [2017] looks into the Late Jurassic-Early Cretaceous paleoenvironmental evolution of small-scale basins in the Transbaikal region. Although the Mongol-Okhotsk orogeny is supposed to occur during this time interval, inducing the growth of a major mountain range, the Transbaikal region is marked by the development of Late Jurassic-Early Cretaceous extensional basins that contradict the expected crustal thickening linked to the Mongol-Okhotsk orogeny. The authors performed a detailed re-evaluation of the paleontological content and sedimentary depositional environments of three Transbaikal basins. They established that extension prevailed continuously from the Early-Middle Jurassic to the Early Cretaceous. The sediment facies evolved from proximal settings (alluvial fans and braided river systems) in the Early-Middle Jurassic to distal (lacustrine) facies in the Early Cretaceous. These results seem to contradict the existence of a high-relief topography in the Transbaikal as advocated by Demonterova and co-authors. The authors suggest that the docking of the Mongolia-North China block to Mongolia was a "soft collision" without formation of a major orogen.

Daoudene et al. [2017] also examine the Mesozoic extension phase but at the scale of Northeast Asia. Indeed, the Mesozoic extensional basins are not restricted to the Transbaikal region but spread eastwards as far as the Pacific coast, generally associated to metamorphic core-complexes (MCCs) and magmatic intrusions, demonstrating a major thinning of the crust. Using structural analysis and ${ }^{40} \mathrm{Ar} /{ }^{39} \mathrm{Ar}$ dating of micas and amphiboles, the authors conclude that the MCCs formed in a narrow time-interval of about $60 \mathrm{Ma}$ from about $160 \mathrm{Ma}$ to $100 \mathrm{Ma}$ without significant trend in ages between the Transbaikal region and the Pacific coast. Published zircon U-Pb ages of the Mesozoic syn-extensional intrusions cluster between 130 and $125 \mathrm{Ma}$, marking the peak of extension. In terms of geodynamics, the authors infer that the peak of extension is correlated both to the closure of the Mongol-Okhotsk ocean and to a change in the direction of convergence between the Izanagi plate and the Eurasian continent. They estimate that a decrease in the normal component of plate convergence might have favored spreading of the East Asian lithosphere, abnormally hot at that time. A double-subduction pattern for the Mongol-Okhotsk ocean would have led to docking of Siberia and Mongolia-North China without formation of a mountain belt. The latter conclusion is in agreement with 
the absence of Middle Jurassic to Early Cretaceous major relief advocated by Jolivet et al. [2017].

Finally, the French Siberian collaboration project allowed to enlarge the circle of participating Universities to Reims and Novossibrisk. Deroin and Buslov [2017] investigated the potential of remote sensing data to describe the geomorphic pattern of a seismically active region. They use the Mw 7.3 earthquake that occurred on 27 September 2003 in Gorny Altai as a case example to demonstrate that a multitemporal, multiscale and multisource remote sensing dataset is a valuable tool in studying the morphotectonic evolution of a seismically active area. For example, they show that this approach is not only a powerful tool to estimate the morphology, volume and frequency of earthquake- triggered landslides but that precursor stages of major landsliding could be detected. Applied to populated areas, this approach could be a major tool in risk-assessment.

Acknowlegements. - We would like to thank all the reviewers of the papers included in this special issue for their prompt response and constructive remarks. Figure 2 was drawn by Anton Kolesnikov.

We are also grateful to J.-L. Teffo and E. Legrand (French Ministry of Education, Higher Education \& Research - DREIC), M. Bonin and C. Danilovic (CNRS-DERCI), V. Vernikovsky, N. Sennikov, N.P. Pokhilenkho, D.P. Gladkochub and E.V. Sklyarov (Russian Acad. Sci., Siberian Branch), F.-O. Seys, V. Level and R. Netter (Univ. Lille), the Direction of the International Office at Univ. Rennes 1 and at last, but not least, O. Lacombe and F. Rangin (Bull. SGF) for their continuous support and patience.

\section{References}

Agashev A.M., Ionov D.A., Pokhilenko N.P., Golovin A.V., Cherepanova Y. \& SHARYGIN I.S. (2013). - Metasomatism in lithospheric mantle roots: Constraints from whole-rock and mineral chemical composition of deformed peridotite xenoliths from kimberlite pipe Udachnaya. - Lithos, 160-161, 201-215.

Bascou J., Doucet L.S., Saumet S., Ionov D.A., Ashchepkov I.V. \& Golovin A.V. (2011). - Seismic velocities, anisotropy and deformation in Siberian cratonic mantle: EBSD data on xenoliths from the Udachnaya kimberlite. - Earth and Planetary Science Letters, 304, 71-84.

Colpaert C., Vachard D., Monnet C., Clausen S., Timokhina I., Obut O. \& IzoKн N. (2017). - Tournaisian (Early Carboniferous) foraminifers of the Kuznetsk Basin (South-West Siberia, Russia). Bull. Soc. géol. Fr., BSGF-Earth Sciences Bulletin, 2017, 188, 2.

Daoudene Y., Gapais D., Cogné J.-P. \& RufFet G. - Late Mesozoic continental extension in northeast Asia - Relationships to plate kinematics. Bull. Soc. géol. Fr., BSGF-Earth Sciences Bulletin, 2017, 188, 10.

De Lagausie B. \& Dzyuba O. S. (2017). - Biostratigraphy of the Bajocian-Bathonian boundary interval in northern Siberia: new data on belemnites from the Yuryung-Tumus peninsula. Bull. Soc. géol. Fr., BSGF-Earth Sciences Bulletin, 2017, 188, 3.

Demonterova E.I., Ivanov A.V., Mikheeva E.M., Arzhannikova A.V., Frolov A.O., Arzhannikov S.G., BryanskiY N.V. \& PaVlova L.A. (2017). - Early to Middle Jurassic history of the southern Siberian continent (Transbaikalia) recorded in sediments of the Siberian Craton: Sm-Nd and U-Pb provenance study. Bull. Soc. géol. Fr., BSGF-Earth Sciences Bulletin, 2017, 188, 8.

Deroin J.-P. \& BusLov M.M. - Geomorphic study of seismically active areas using remote sensing data. Case of the Gorny Altai (Siberia) affected by the 2003 Altai Earthquake. Bull. Soc. géol. Fr. BSGF-Earth Sciences Bulletin, 2017, 188, 11.

D'Eyrames E., Thomassot E., Kitayama Y., Golovin A.V., Korsakov A.V. \& IoNOv D.A. (2017). - A mantle origin for sulphides in the unusual "salty" Udachnaya-East kimberlite from sulphur abundances, speciation and isotopes. Bull. Soc. géol. Fr. BSGF-Earth Sciences Bulletin, 2017, 188, 6.

Doucet L.S., Ionov D.A., Golovin A.V. \& PoKhilenko N.P. (2012). Depth, degrees and tectonic settings of mantle melting during craton formation: inferences from major and trace element compositions of spinel harzburgite xenoliths from the Udachnaya kimberlite, central Siberia. - Earth and Planetary Science Letters, 359-360, 206-218.

Doucet L., Ionov D. \& Golovin A. (2013). - The origin of coarse garnet peridotites in cratonic lithosphere: new data on xenoliths from the Udachnaya kimberlite, central Siberia. - Contributions to Mineralogy and Petrology, 165, 1225-1242.
Doucet L.S., Peslier A.H., Ionov D.A., Brandon A.D., Golovin A.V., Goncharov A.G. \& AshchePKov I.V. (2014). - High water contents in the Siberian cratonic mantle linked to metasomatism: An FTIR study of Udachnaya peridotite xenoliths. - Geochimica et Cosmochimica Acta, 137, 159-187.

Doucet L.S., Ionov D.A. \& Golovin A.V. (2015). - Paleoproterozoic formation age for the Siberian cratonic mantle: Hf and Nd isotope data on refractory peridotite xenoliths from the Udachnaya kimberlite. - Chemical Geology, 391, 42-55.

Doucet L.S., Mattielli N., Ionov D.A., Debouge W. \& Golovin A.V. (2016). - $\mathrm{Zn}$ isotopic heterogeneity in the mantle: A melting control? - Earth and Planetary Science Letters, 451, 232-240.

Ferré E.C., Friedman S.A., Martín-Hernández F., Feinberg J.M., Conder J.A. \& Ionov D.A. (2013). - The magnetism of mantle xenoliths and potential implications for sub-Moho magnetic sources. - Geophysical Research Letters, 40 (1), 105-110, doi:10.1029/2012GL054100.

Goncharov A.G., Ionov D.A., Doucet L.S. \& PoKhilenko L.N. (2012). Thermal state, oxygen fugacity and $\mathrm{C}-\mathrm{O}-\mathrm{H}$ fluid speciation in cratonic lithospheric mantle: new data on peridotite xenoliths from the Udachnaya kimberlite, Siberia. - Earth and Planetary Science Letters, 357-358, 99-110.

GrazhDANKIN D. (2014). - Patterns of evolution of the Ediacaran soft-bodied biota. - Journal of Paleontology, 88 (2), 269-283.

Grazhdankin D. \& Gerdes G. (2007). - Ediacaran microbial colonies. Lethaia, 40, 201-210.

Ionov D.A., Doucet L.S. \& AshCHEPKov I.V. (2010). - Composition of the lithospheric mantle in the Siberian craton: new constraints from fresh peridotites in the Udachnaya-East kimberlite. - Journal of Petrology, 51, 2177-2210.

Ionov D.A., Carlson R.W., Doucet L.S., Golovin A.V. \& Oleinikov O.B. (2015a). - The age and history of the lithospheric mantle of the Siberian craton: Re-Os and PGE study of peridotite xenoliths from the Obnazhennaya kimberlite. - Earth and Planetary Science Letters, 428, 108-119.

Ionov D.A., Doucet L.S., Carlson R.W., Golovin A.V. \& Korsakov A.V. (2015b). - Post-Archean formation of the lithospheric mantle in the central Siberian craton: Re-Os and PGE study of peridotite xenoliths from the Udachnaya kimberlite. - Geochimica et Cosmochimica Acta, 165, 466-483.

Jean M.M., Taylor L.A., Howarth G.H., Peslier A.H., Fedele L., BodNAR R.J., Guan Y., Doucet L.S., Ionov D.A., Logvinova A.M., Golovin A.V. \& Sobolev N.V. (2016). - Olivine inclusions in Siberian diamonds and mantle xenoliths: Contrasting water and trace-element contents. - Lithos, 265, 31-41. 
Jolivet M., Arzhannikova A., Frolov A., Arzhannikov S., Kulagina N., Akulova V. \& Vassallo R. (2017). - Late Jurassic-Early Cretaceous paleoenvironmental evolution of the Transbaikal basins (SE Siberia): implications for the Mongol-Okhotsk orogeny. Bull. Soc. géol. Fr., BSGF-Earth Sciences Bulletin, 2017, 188, 9.

Kolesnikov A., Grazhdankin D.V. \& Maslov A.V. (2012). - Arumberiatype structures in the Upper Vendian of the Urals. - Doklady Earth Sciences, 447 (1), 1233-1239.

Kolesnikov A.V., Marusin V.V., Nagovitsin K.E., Maslov A.V. \& GRAZHDANKIN D.V. (2015). - Ediacaran biota in the aftermath of the Kotlinian Crisis: Asha Group of the South Urals. - Precambrian Research, 263, 59-78.

Kolesnikov A., Danelian T., Gommeaux M., Maslov A.V. \& GrazhdanKIN D.V. (2017). - Arumberiamorph structure in modern microbial mats: implications for Ediacaran palaeobiology. Bull. Soc. géol. Fr., BSGF-Earth Sciences Bulletin, 2017, 188, 5.

Korovnikov I.V., Sennikov N.V., Danelian T., Obut O.T. \& Poullle L. (2013). - The biostratigraphic and palaeoenvironmental significance of lower Cambrian (Botomian) trilobites from the Ak-Kaya section of the Altai Mountains (southern Siberia, Russia). - Annales de Paléontologie, 99, 79-89.

Kouchinsky A., Bengtson S., Clausen S. \& Vendrasco M.J. (2015). An early Cambrian fauna of skeletal fossils from the Emyaksin Formation, northern Siberia). - Acta Palaeontologica Polonica, 60, 421-512.

Moyen J.-F., Paquette J.-L., Ionov D.A., Gannoun A., Korsakov A.V., Golovin A.V. \& Moine B.N. (2017). - Paleoproterozoic rejuvenation and replacement of Archaean lithosphere: Evidence from zircon $\mathrm{U}-\mathrm{Pb}$ dating and $\mathrm{Hf}$ isotopes in crustal xenoliths at Udachnaya, Siberian craton. - Earth and Planetary Science Letters, 457, 149-159.

Nimis P., Goncharov A., Ionov D. \& McCammon C. (2015). - Fe ${ }^{3+}$ partitioning systematics between orthopyroxene and garnet in mantle peridotite xenoliths and implications for thermobarometry of oxidized and reduced mantle rocks. - Contributions to Mineralogy and Petrology, 169, 1-18.
OBut O.T. \& IwATA K. (2000). - Lower Cambrian Radiolaria from the Gorny Altai (southern West Siberia). - News of Paleontology and Stratigraphy, 2-3, 33-37. Suppl. to the journal "Russian Geology and Geophysics", 41.

Pouille L., Obut O., Danelian T. \& Sennikov N. (2011). - Lower Cambrian (Botomian) polycystine Radiolaria from the Altai Mountains (southern Siberia, Russia). - Comptes Rendus Paleovol, 10, 627-633.

Radu I.B., Moine B.N., Ionov D.A., Korsakov A.V., Golovin A.V. \& CotTin J.Y. (2017). - Kyanite-bearing eclogite xenoliths from the Siberian craton, Russia. Bull. Soc. géol. Fr., BSGF-Earth Sciences Bulletin, 2017, 188, 7.

Sennikov N.V., Korovnikov I.V., Obut O.T., Tokarev D.A., Novozhilova N.V. \& Danelian T. (2017). - The Lower Cambrian of the Salair and Gorny Altai (Siberia) revisited. Bull. Soc. géol. Fr., BSGF-Earth Sciences Bulletin, 2017, 188, 1.

Seuru S., Leshchinskiy S., Auguste P. \& Fedyaev N. (2017). - Wooly mammoth and Man at Krasnoyarskaya Kurya site, West Siberian Plain, Russia (excavation results of 2014). Bull. Soc. géol. Fr., BSGF-Earth Sciences Bulletin, 2017, 188, 4.

Won M.-Z. \& BELOw R. (1999). - Cambrian Radiolaria from the Georgina Basin, Queensland, Australia. - Micropaleontology, 45, 325-363.

Xia J., Qin L., Shen J., Carlson R.W., Ionov D.A. \& Mock T.D. (2017). Chromium isotope heterogeneity in the mantle. - Earth and Planetary Science Letters 464, 103-115, doi: 10.1016/j.eps1.2017.01.045.

Zybin V.A., Sennikov N.V., Iwata K., Obut O.T., Kurtigeshev V.S., Khlebnikova T.V. \& Sugai Y. (2000). - New data on the microfauna and geologic structure of the areas of development of the lower Cambrian Shashkunar silico-carbonate-terrigenous Formation (Gorny Altai). - Russian Geology and Geophysics, 41 (4), 499-516. 